\title{
Learning Arabic in the Overseas Factories: The Case of the English*
}

\author{
Simon Mills \\ Introduction: The Claims of Scholarship
}

One of the arguments consistently advanced for studying Arabic in early modern Europe was the practical utility of the language in light of Europe's growing mercantile and diplomatic relations with the Arabic-speaking world. In the preface which they added to their father's pioneering Arabic-Latin dictionary (the first ever printed), the Raphelengius brothers explained that one of the motives that had urged their father to undertake the work was his frequently being asked by merchants of his acquaintance to interpret Arabic letters for them. ${ }^{1}$ In 1620 the first full professor of Arabic at the University of Leiden, Thomas Erpenius, advised his students that they 'could not fail to recognise' how useful a knowledge of Arabic - the common language of Egypt, Libya, costal Africa, Arabia, and Palestine - would be for the purpose of 'African and Asiatic journeys.'2 In 1648 the German scholar, Christian Ravius, recommending a knowledge of even a smattering of Arabic to his contemporaries in the

* My thanks to Alastair Hamilton for his comments on an earlier draft of this article.

1 F. Raphelengius, Lexicon Arabicum, Leiden, 1613, sig. A3 $3^{\mathrm{r}}$ ' $\mathrm{Nec}$ minus eum stimulavit cupiditas gratificandi mercatoribus quibusdam ipsi familiaribus \& longo usu coniunctissimis, qui literas Arabice scriptas, ad tutelam plerunque navium \& negotiatorum pertinentes, ut explicaret saepenumero eum rogarunt'; quoted in A. Hamilton, William Bedwell the Arabist 1563-1632, Leiden, 1985, p. 151. On Raphelengius's dictionary see A. Hamilton, "Nam tirones sumus": Franciscus Raphelengius' Lexicon Arabico-Latinum (Leiden 1613)', in Ex officina Plantiniana. Studia in memoriam Christophori Plantini (ca.1520-1589), eds M. De Schepper and F. De Nave, Antwerp, 1989, De Gulden Passer, 66-67, 1988-89, pp. 557-89.

2 T. Erpenius, Orationes tres, de linguarum Ebraeae, atque Arabicae dignitate, Leiden, 1621, p. 70 : 'Quantae autem utilitatis Arabum lingua sit, in peregrinationibus Africanis, atque Asiaticis, ignorare non potestis, qui scitis in Aegypto, Lybia, totaque Africa litorali, itemque in Arabia, \& Palaestina, vulgarem eam esse, \& solam in usu'. For a translation, see R. Jones, 'Thomas Erpenius (1584-1624) on the Value of the Arabic Language', Manuscripts of the Middle East: A Journal devoted to the Study of Handwritten Materials of the Middle East, 1, 1986, pp. 15-25. 
commercial world, declared that: 'a Merchant that can onely prattle, shall buy any ware cheaper, and at a better rate, than he that can speake nothing'.

On the face of it, these arguments were reasonable enough. The scholarly study of Arabic, especially as it developed in France, the Netherlands, and England, was closely intertwined with these countries' diplomatic and mercantile interests in North Africa and the Levant. Many of the most distinguished Arabists of the sixteenth and seventeenth centuries - men such as Guillame Postel, André du Ryer, Jacobus Golius, and Edward Pococke - gained first-hand experience of the Arabic-speaking world in the service of European embassies or commercial enterprises. Scholars occasionally served their governments by translating diplomatic correspondence, and at least one of the professorial chairs in Arabic established in the seventeenth century (the Thomas Adams professorship of Arabic at Cambridge) was funded by a merchant. However, in other respects these arguments were problematic. Firstly, although Europeans did trade in cities with large Arabic-speaking populations, such as Aleppo and Cairo, the seat of European diplomacy with the Ottoman Empire (which by the sixteenth century included Egypt, Syria, Palestine, and parts of Arabia) was in Istanbul. Here, it was not Arabic, but Turkish which served as the primary medium of communication; it might thus have been argued justly that Turkish, rather than Arabic, would have proved more useful to the requirements of diplomacy. Secondly, the stress on the practical usage of Arabic masked a divergence of interests between scholars and their contemporaries in the commercial and diplomatic spheres. Broadly speaking, Arabic studies were pursued in the early modern European universities for two reasons. On the one hand, it was conceived that knowledge bearing on various branches of the sciences, in particular mathematics, medicine, and astronomy, had been preserved in Arabic texts, sometimes as translations of ancient Greek authors and sometimes as original contributions. In many ways, this was a continuation of an urge which had impelled the study of Arabic in Europe in the Middle Ages. On the other hand, an interest in Arabic was spurred by the humanistic approach to interpreting the Bible. Scholars both hoped to profit from versions of the biblical texts preserved in Arabic by the various eastern churches, and to draw on Arabic literature in an attempt to reconstruct a linguistic and broader historical context within which to understand the Hebrew Old Testament. Neither of these two reasons had very much to do with the practical business of trade and diplomacy in the contemporary Arabic-speaking world. It is worth adding too that Arabic - more than any European language - differs in its written and spoken forms. Early modern scholars were almost exclusively

3 C. Ravis, A Discourse of the Orientall Tongues, London, 1648, p. 30. 
concerned with written classical Arabic, the Arabic of the Qur'an and the literary tradition. Conversely, they paid virtually no attention to spoken Arabic or to the regional variations of the language in use across North Africa and the Middle East.

These two divergent motivations for learning Arabic - the practical requirements of the merchant and the antiquarian interests of the scholar - are also apparent when we turn from the universities to the overseas settlements, or 'factories', of European merchants. Taking as its focus the English mercantile communities, this article asks whether, how, and to what extent Arabic was studied among the merchants and consular officials stationed in the Arabicspeaking world. As we shall see, the impetus for merchants to engage in any substantial attempt to acquire a knowledge of Arabic in the early English settlements in the Levant and North Africa was limited, although by no means non-existent. However, the overseas factories came to provide an opportunity for individuals with a range of scholarly interests, independent of the immediate concerns of trade or diplomacy, to further their linguistic pursuits. This began to change in the second half of the eighteenth century, when the developing bureaucracy of the East India Company provided a new stimulus to the formal study of Arabic.

\section{The Ottoman Levant}

The first and most enduring English merchant community in the Arabicspeaking world was that of Aleppo in Syria. Even before the foundation of the English Levant Company in 1581, Aleppo had emerged as an important centre for English trade. In 1553 the indefatigable Anthony Jenkinson was in the city and was granted permission by Sultan Süleyman (known to the west as 'the Magnificent') to trade on an equal footing with the Venetians and the French. By 1583 the Levant Company had a consul for Syria, and three years later Aleppo replaced Tripoli as the consul's chief residence. By the early seventeenth century, there were around twenty English merchants resident in the city, who met regularly in the Khan al-Burghul. ${ }^{4}$ By 1680 this number had more than doubled, and the English had moved into the large and imposing Khan al-Gumruk. Although the community had shrunk to around thirteen members

4 TNA, SP 110/54, 'Minute book of the Court of the Consul and British Factory at Aleppo, with chancery register, concerning commercial disputes, wills and inventories'. 
by the 1760 s, it lingered on until the dissolution of the Levant Company in the early nineteenth century. ${ }^{5}$

Did any of these merchants learn Arabic? Firstly, it is important to point out that although Arabic was widely spoken in Aleppo, it was far from being the only language used in the city. When the Englishman Charles Robson arrived in Aleppo in 1623 he found it 'an Epitome of the whole world [...] there scarce being a Nation [...] who hath not some trading here or hither', a situation confirmed by recent historical research. ${ }^{6}$ This ethnic mix was characteristic of Aleppo throughout the early modern period and was matched by a corresponding linguistic diversity. More than a century after Robson was in the city, the Levant Company chaplain Thomas Dawes reported from Aleppo that 'it is not uncommon in one day to be in the company of different nations, whose speech seems nothing but confusion, French, Italian, Latin, Greek, Dutch, German, Turkish, Arab \& Armenian'? Amidst this cacophony of languages, Italian - the lingua franca of the eastern Mediterranean - served in Aleppo, as it did throughout the ports and commercial centres of the Levant, as a common medium of exchange. ${ }^{8} \mathrm{~A}$ basic knowledge of Italian was therefore likely to have been of as much if not more immediate practical use than any Oriental language. William Maye, a chaplain who served the Levant Company in Aleppo at the end of the sixteenth century, knew some Italian, and was able to use this to converse with two Turks on the island of Rhodes. ${ }^{9}$ John Kymaston, a merchant who died in Aleppo in 1633, left among his belongings an Italian

5 The best general history of the Levant Company remains A.C. Wood, A History of the Levant Company, London, 1935. On the Aleppo trade in the eighteenth century, see R. Davis, Aleppo and Devonshire Square: English Traders in the Levant in the Eighteenth Century, London, 1967. J. Mather, Pashas: Traders and Travellers in the Islamic World, New Haven, СT, 2009, provides a lively account of life in the English overseas factories.

6 C. Robson, Newes from Aleppo, London, 1628, p. 14; B. Masters, 'Aleppo: the Ottoman Empire's Caravan City', in The Ottoman City between East and West: Aleppo, Izmir, and Istanbul, eds E. Eldem, D. Goffman, and B. Masters, Cambridge, 1999, pp. 34-5 where Masters has shown that - in addition to the European communities - there were resident merchants in Aleppo from North Africa, India, and Bukhara, and that traders from Egypt, Yemen, Damascus, Ankara, Mosul, and Salonika were active in the commerce of the city.

7 T. Dawes to C. Lyttelton, 1 Mar. 1763 , BL, MS Stowe 754 , fols $85^{\mathrm{r}}-85^{\mathrm{v}}$.

8 See, in particular, E.R. Dursteler, 'Speaking in Tongues: Language and Communication in the Early Modern Mediterranean', Past and Present, 217.1, 2012, pp. 47-77.

9 This, however, did not prevent him from being kidnapped and ransomed; see the relation of the incident by Thomas Dallam in J.T. Bent, Early Voyages and Travels in the Levant, London, 1893, pp. 36-9. 
dictionary, and several books in the same language. ${ }^{10}$ From documents preserved in the chancery register it is clear that Italian was used by the English for drawing up contracts during this period. This reliance on Italian continued through the seventeenth and well into the eighteenth century. The linguist and author Giovanni Torriano dedicated his 1659 Italian-English dictionary to the Levant Company; judging his work 'very usefull for all young Merchants', the Levant Company agreed to pay him a gratuity the following year. ${ }^{11}$ Torriano's Italian grammar was among the books held in the factory's library in Aleppo by 1688. ${ }^{12}$ As late as 1763 , Thomas Dawes reported from Aleppo that:

Italian is the general language of the mercantile world, but that is pronounced in a different way by each different person, so that what is intelligible in the mouth of one, is quite the reverse in that of another; \& by this mixture of languages \& this variety of pronunciation there is sprung up a motley kind of speech, called here lingua franca. ${ }^{13}$

Furthermore, the English merchants were spared the necessity of learning foreign languages in Aleppo by their reliance on dragomans (from the Arabic 'tarjama', 'to translate'), who acted as intermediaries with the Ottoman authorities and local merchants. From the 1590s, the vice-consul maintained a dragoman in Aleppo. ${ }^{14}$ In the early seventeenth century, the post was filled by a certain Farajallāh Çelebi, who appears to have been succeeded by his son, 'Thoma John', in the $1630 .^{15}$ By the last decades of the 16oos, two dragomans served the factory, and these positions continued to be occupied throughout the eighteenth century. ${ }^{16}$ Following the example of the Venetians and the French, the English did experiment with providing English youths with the necessary linguistic training to serve the Company. However, this did not on the whole prove successful, and all of the dragomans who served in Aleppo

10 TNA, SP $110 / 54$, fol. $205^{\mathrm{v}}$.

11 G. Torriano, Vocabolario Italiano \& Inglese: A Dictionary Italian \& English, London, 1659; TNA, SP $105 / 152$, fol. $4^{v}$. See also TNA, SP 105/149, fol. $201^{\mathrm{v}}$ ordering a gratuity to Torriano on account of his dedicating his Italian grammar to the Levant Company.

12 TNA, SP 105/145, fol. 163.

13 Dawes to Lyttelton, 1 Mar. 1763 , BL, MS Stowe 754 , fol. $85^{\mathrm{v}}$. More generally on the topic of lingua franca and its use throughout the Levant, see J. Dakhlia, Lingua franca: Histoire d'une langue métisse en Méditerranée, Arles, 2008, esp. pp. 147-91.

14 R. Fitch and others to G. Dorrington, 4 Aug. 1596, in The Travels of John Sanderson in the Levant 1584-1602, ed. W. Foster, London, 1931, p. $15^{2}$.

15 TNA, SP $105 / 148$, fols $34^{\mathrm{v}}, 36^{\mathrm{r}}$; TNA, SP $110 / 54$, fols $195^{\mathrm{r}}, 108^{\mathrm{r}}, 145^{\mathrm{r}}$.

16 TNA, SP $105 / 155$, fol. $103^{\mathrm{V}}$. 
appear to have been recruited from among the locals, either Sephardic Jews, Levantine Christians, or - increasingly during the eighteenth century - Arab Catholics. ${ }^{17}$

These two factors, combined with the innate difficulty of the language and the inaccessibility of most aspects of the social life of Aleppo, no doubt contributed to discouraging serious attempts to learn Arabic among the English merchant community. This general lack of interest in Oriental languages has been noted often, both in contemporary descriptions of the English factory in Aleppo and in more recent historical accounts. ${ }^{18}$ Nevertheless, there were certainly some exceptions to this general rule. Documents in the early chancery registers show that the English factors came into contact with Arabic. Many of the consuls and merchants resided in Aleppo for a decade, and it is hard to believe that during this time they would not have picked up at least scraps of the native language. Moreover, the reports of some contemporaries paint a slightly different picture to the usual one of a complete lack of interest. The Englishman George Sandys, who visited the Levant in the early 161os, thought the consul in Aleppo, Bartholemew Haggatt, 'expert in their language.'19 The French traveler the Abbé Carré noted that Benjamin Lannoy, the English consul in Aleppo for over a decade during the 1660s and 1670s, was 'well versed in all languages'. ${ }^{20}$ Writing in the late 1720 s, Daniel Defoe mentioned 'a Turkey merchant' of his acquaintance who 'had liv'd at Aleppo, at Constantinople, and at Grand Cairo' and who 'spoke the Arabic in all its several dialects as spoken by the Turks at all those places.' ${ }^{21}$ It is perhaps easy to be sceptical about these statements (what, for example, are we to make of Defoe's reference to

17 B. Masters, Christians and Jews in the Ottoman Arab World: The Roots of Sectarianism, Cambridge, 2001, pp. 71-7.

A. Russell, The Natural History of Aleppo, 2 vols, London, 1794, vol. 1, p. 227. Wood, A History of the Levant Company, p. 236; Davis, Aleppo and Devonshire Square, p. 80; B. Masters, The Origins of Western Economic Dominance in the Middle East: Mercantilism and the Islamic Economy in Aleppo 1600-1750, New York, 1988, p. 78.

19 G. Sandys, A Relation of a Journey begun An: Dom: 1610, 4th edn, London, 1632, p. 85.

20 The Travels of Abbé Carré in India and the Near East 1672-1674, transl. Lady Fawcett, ed. C. Fawcett and R. Burn, 3 vols, London, 1947-48, vol. 1, p. 42. It is worth comparing this with the French consul Laurent d'Arvieux's comment about the Dutch consul in Aleppo, Conrad Calckberner: 'Il parlait, lisait et écrivait le français, l'anglais, l'italien et l'arabe comme sa langue maternelle', Laurent d'Arvieux, 'Mémoires du Chevalier d'Arvieux (1735)', in Le Consulat de France à Alep au XVII e siècle:Journal de Louis Gédoyn, Vie de François Picquet, Mémoires de Laurent d'Arvieux, eds H.I. El-Mudarris and O. Salmon, Aleppo, 2009, p. 226. bank, 10 vols, London, 2006-7, vol. 10, ed. W.R. Owens, p. 165. 
the Arabic 'spoken by the Turks'?) It is much harder to ascertain what linguistic competence might have meant in particular historical situations. ${ }^{22}$ What did it really mean to be 'well versed' or 'expert' in a language such as Arabic? The examples that have come down to us allow us to picture merchants using Arabic for a variety of social functions. John Brand Kirkhouse, for example, a Scottish merchant resident in Aleppo in the 1750 os, who was said to know 'Sundry Languages, viz the Arab-Turkish, Greek, Italian \& French', apparently entertained the factory with his ability to 'sing in all these languages'. ${ }^{23}$ In his role as chancellor to the factory, Brand Kirkhouse regularly witnessed contracts in Arabic drawn up by the dragoman Jirjis 'Āida; we might conjecture that he knew enough of the language to feel comfortable fulfilling this task.

Signs of a more substantial knowledge of Arabic are more evident when we turn to merchants who developed interests in the Levant independent from their immediate concerns as traders. Particularly noteworthy in this respect is the case of Rowland Sherman. Sherman spent the extraordinarily long period of just under sixty years in Aleppo, from his arrival in October 1688 until his death in January 1748 at the age of around eighty-five. As well as pursuing a career as a successful merchant, Sherman cultivated a range of interests during the six decades he spent in Aleppo, not least developing his skills as an amateur musician. ${ }^{24} \mathrm{He}$ was also a keen linguist: he not only corresponded in Italian, ${ }^{25}$ but also turned his hand to learning Turkish and Arabic. In 1699 Sherman reported to his colleague in London Philip Wheak that he had for the previous three years 'bent my studies pretty close to Turkish, \& have made some progress in reading \& writing it', even translating a short tract on Islam from Turkish into English. ${ }^{26}$ His interest in Arabic was even more longstanding; he studied the language under the Maronite priest Pietro de Oliva, and by 1720 was said by Samuel Lisle, who had known Sherman in Aleppo, to have 'acquired a perfect Knowledge of the Arabick Tongue which he speaks and Writes with great Elegance and Purity'. ${ }^{27}$ Sherman's proficiency in Arabic and

22 On the topic of linguistic competence I have learned a great deal from John Gallagher's Cambridge PhD thesis, 'Vernacular Language-Learning in Early Modern England', 2014, and I am very grateful to him for sharing it with me.

23 TNA, SP 110/74, 8 Nov. 1753.

24 B. White, "Brothers of the String": Henry Purcell and the Letter-Books of Rowland Sherman', Music and Letters, 92.4, 2011, pp. 519-81.

25 For a selection of Sherman's Italian letters, see White, “'Brothers of the String"' pp. 550-72.

26 TNA, SP 110/21, fol. $24^{\mathrm{v}}$; quoted at length in White, "Brothers of the String"', p. 547.

27 S. Lisle to H. Newman, 26 May 1720, CUL, SPCK D5/4, p. 16; on Sherman's tutor, see R. Sherman to H. Newman, 20 Apr. 1725, CUL, SPCK D5/4, p. 86. 
connections to the Christian churches in Syria brought him to the attention of the Society for Promoting Christian Knowledge. In the 1720 and 1730 Sherman was closely involved with the production and distribution of Arabic editions of the Psalms and the New Testament printed in London under the auspices of the SPCK. In 1738 the traveler Richard Pococke reported from Aleppo that Sherman 'understands Arabick perfectly'. ${ }^{28}$

Similarly, the brothers Alexander and Patrick Russell, who served overlapping terms as physicians to the factory in Aleppo between 1740 and 1772, added to their broad interests in the natural history of Syria at least some knowledge of Arabic. Both brothers learned enough of the vernacular to practice medicine among the local Arabs, and Patrick, who was considered something of an authority on classical Arabic, collected Arabic literary manuscripts. ${ }^{29}$

The most notable examples of this more scholarly interest in Arabic can be found among the Church of England chaplains who served the English merchant community throughout the seventeenth and eighteenth centuries. Of these, the best known was Edward Pococke. Pococke arrived in Aleppo in 1630. For the next six years he devoted what time he could to his linguistic studies, in the memorable phrase of the consul John Wandesford making 'Arrab his mistress'. ${ }^{30}$ The humanistic education Pococke had received as a student at Oxford would have trained him in the skills necessary for the private study of languages and this was no doubt how he proceeded: working through the Qur'an and preparing a Latin translation of the proverbs (amthāl) of the Islamic jurist and legal theorist al-Maydānī. ${ }^{31}$ Yet Pococke also hired a number of native speakers to assist him with his studies: the 'shaykh' Fathallāh and a servant

28 Pococke to his mother, 12/23 Aug. 1738, Letters from Abroad: The Grand Tour Correspondence of Richard Pococke \& Jeremiah Milles, ed. R. Finnegan, 3 vols, Piltown, 2013, vol. 3, p. 158. Note that I read this passage differently from Finnegan, who takes it that Pococke is referring to the French consul.

29 M.H. van den Boogert, Aleppo Observed: Ottoman Syria through the Eyes of Two Scottish Doctors, Alexander and Patrick Russell, Oxford, 2010, pp. 148, 218-19.

30 J. Wandesford to J. Selden, 26 Nov. 1632, Bodl. Oxf., Ms Selden supra 108, fol. $25^{\mathrm{r}}$, quoted in G.J. Toomer, Eastern Wisedome and Learning: The Study of Arabic in Seventeenth Century England, Oxford, 1996, p. 70. On Pococke's years in Aleppo, see Toomer, Eastern Wisedome, pp. 120-26.

L. Twells, ed., The Theological Works of the Learned Dr. Pococke, 2 vols, London, 1740, vol. 1, p. 6. Pococke's translation of al-Maydānī survives as Bodl. Oxf., Ms Pococke 392; see P.M. Holt, 'The Study of Arabic Historians in Seventeenth Century England: The Background and Work of Edward Pococke', Bulletin of the School of Oriental and African Studies, 19.3, 1957, pp. 444-55 (448) (repr. P.M. Holt, Studies in the History of the Near East, London, 1973, pp. 27-49). 
named Hamid, from the last of whom he endeavoured to acquire the spoken form of the language. ${ }^{32}$ In addition to these individuals - named by Pococke's eighteenth-century biographer - Pococke was aided in his Arabic studies by the dervish Ahmmad al-Gulshanī, very likely an adherent of the Gulshaniyya sect of Sufis, who acted variously as a teacher, a copyist, and a broker for a number of Europeans with scholarly interests in Arabic. Al-Gulshanī was one of various native Arabic speakers who capitalized on the rising European interest in Arabic by providing lessons to visiting students. He numbered both Pococke and the Dutch Arabist Jacobus Golius among his pupils, corresponded in Arabic with both men following their return journeys to Europe, and continued from a distance to take an interest in their progress in their linguistic studies. $^{33}$

A similar example from later in the century is provided by the chaplain Robert Frampton. In the 165os Frampton studied Arabic in Aleppo. Frampton's biographer provides telling glimpses of Frampton using the language for different ends. He apparently progressed so far in both reading and speaking that he was able to compile a collection of Arabic proverbs, to intercede with local officials in Aleppo, and to ward off a band of thieves on the road to Istanbul. ${ }^{34}$

32 Twells, Works, vol. 1, p. 6.

33 See Bodl. Oxf., Ms Pococke 432 fols 5-9 for al-Gulshani’s letters to Pococke. Excerpts from these letters have been translated and printed in Holt, Studies in the History of the Near East, pp. 42-5. See also Toomer, Eastern Wisedome, pp. 122-3; H. Kilpatrick, 'Arabic Private Correspondence from Seventeenth-Century Syria: The Letters to Edward Pococke', Bodleian Library Record, 23.1, 2010, pp. 20-40. For al-Gulshanī's letters to Golius see LUL, MS Or. 1228, fols $26^{\mathrm{r}}, 90^{\mathrm{v}}$. The Arabic text and a Dutch translation is printed in M. Th. Houtsma, Uit de Oostersche Correspondentie van Th. Erpenius, Jac. Golius en Lev. Warner. Eene Bijdrage tot de geschiedenis van de beoefening der oostersche letteren in Nederland, Amsterdam, 1887, p. 48-50. A further letter from al-Gulshanī to Golius survives in a copy among the papers of Nicolas-Claude Fabri de Peiresc (identified by Peter Miller), BNF, MS Latin 9340, fols 295 ${ }^{\mathrm{r}}-301^{\mathrm{v}}$. Al-Gulshanī addressed both Pococke and Golius as تلميذ (pupil). In one of his letters to Pococke (Bodl. Oxf., Ms Pococke 432, fol. $7^{\mathrm{v}}$ ) al-Gulshanī addresses Pococke as المفحّص عن اصول اللغة العربية (the researcher into the fundamentals of the Arabic language'). In a letter to Golius (BNF, Ms Latin 9340, fol. 300v), al-Gulshānī wrote: و'I am desirous that you ونخن مرادنا ترسل لنا رسالة بالمنصوص حتى نعلم حد ما وصلت اليه من العربية send me a letter, and in particular so that I might know the degree to which you have attained in Arabic'). My thanks to Alasdair Watson for his help in deciphering this passage.

34 T. Simpson Evans, ed., The Life of Robert Frampton Bishop of Gloucester, London, 1876, pp. 38-9, 42, 70. The origins of this work are slightly obscure: it was based on a manuscript (BL, Add. MS 32010) which was acquired by the British Library in 1833, and which appears to have been written by someone who knew Frampton intimately. See A. Hamilton, "The English Interest in the Arabic-Speaking Christians' in The 'Arabick' Interest of the Natural 
The same source offers some insight into how Frampton studied the language. Having learned to read with the aid of books, Frampton was only able to achieve a degree of fluency by abandoning book learning, finding 'observation the readyest way to an ability of converse. ${ }^{35}$ Likewise, Isaac Basire, a royalist Anglican, who, like Frampton, had travelled to the Levant to avoid political compromise at home, 'picked up' some Arabic at Aleppo in the early 1650 s. $^{36}$ More than a century later, Thomas Dawes also used his leisure hours to 'make an attempt on some of the languages'. Yet Dawes thought the merchants those with 'a necessary intercourse with both natives \& foreigners' - better placed to progress in languages than himself; 'I, who stand aloof, \& am but a spectator of the busy world', he complained, 'can gain nothing but by dint of study' 37

A catalogue of the books in the factory's library drawn up in 1688 provides an insight into the materials available to men such as Frampton and Dawes who studied Arabic during their years in Aleppo. ${ }^{38}$ The library possessed the Arabic grammar by the German Lutheran Matthias Wasmuth. ${ }^{39}$ Wasmuth's Grammatica Arabica (1654) was itself closely modelled on the most influential Arabic grammar produced in seventeenth-century Europe: Thomas Erpenius's Grammatica Arabica of $1613 .{ }^{40}$ Wasmuth's edition was indicative of the scholarly-antiquarian (as opposed to the utilitarian) study of Arabic: the book contained a preface recommending a knowledge of Arabic as ancillary to the study of Hebrew. Likewise, the few printed Arabic books available to potential students in Aleppo would have provided little in the way of practical assistance. The library held the translation of Robert Bellarmine's Doctrina

Philosophers in Seventeenth-Century England, ed. G.A. Russell, Leiden, 1994, pp. 30-53 (42).

Simpson Evans, ed., Life of Frampton, p. 113. This passage also notes that Frampton's nephew was with him in Aleppo, and had learned to speak Arabic fluently by 'playing in the Street'.

36 D. Goffman, Britons in the Ottoman Empire 1642-166o, Seattle, 1998, p. 216.

37 Dawes to Lyttleton, BL, MS Stowe 754 , fol. $85^{\mathrm{r}}$.

38 TNA, SP 105/145, fols $157-64$. Frampton was instrumental in selecting the books for the library with a grant of $£_{50}$ from the Levant Company, see TNA, SP 105/151, fol. 131 .

39 M. Wasmuth, Grammatica Arabica, Amsterdam, 1654. On Wasmuth see C. Siegfried, 'Wasmuth, Matthias', in Allgemeine Deutsche Biographie, 56 vols, Leipzig, 1875-1912, vol. 41, 1896, pp. 230-32.

40 T. Erpenius, Grammatica arabica, Leiden, 1613. On the history of European grammars of Arabic, see A. Hamilton, 'Arabic Studies in Europe', in Encyclopedia of Arabic Language and Linguistics, General Editor K. Versteegh, 5 vols, Brill, 2006-9, vol. 1, pp. 166-72, (1679). Wasmuth's biographer found that his grammar 'nichts Eigenes enthalten zu haben scheint, sondern im wesentlichen auf Erpenius beruhte'. 
Christiana printed at Rome in 1627 , the version of Hugo Grotius's De veritate religionis Christianae translated into Arabic by Pococke, and the Arabic texts of the Old and New Testaments printed in the London Polyglot Bible.

The other major English settlements in the Ottoman Levant - Istanbul and Izmir - were in predominantly Turkish speaking cities. Nevertheless, they appear to have provided some limited opportunities for studying Arabic. Henry Denton spent four years as chaplain to the English ambassador in Istanbul where he studied some Arabic and Turkish. ${ }^{41}$ Thomas Smith did the same in the early $1670 \mathrm{~s}$. Another university graduate who used a posting to one of the Levant Company's chaplaincies to pursue the study of Oriental languages was John Luke. Luke was appointed to serve as chaplain to the English factory at Izmir in $1664{ }^{42}$ In his extant journal from these years he noted the 'paines and dollars' he spent in 'attempting some knowledge of the Turkish language', and he appears too to have turned his hand to Arabic, possibly with the help of native speakers. ${ }^{43}$ As he travelled through Turkey and Syria on an extended pilgrimage to Jerusalem, Luke wrote out in an Arabic script with full diacritical markings the names of the various towns and villages he passed through. Judging by his frequently erroneous spelling, it is likely that he heard these directly from a local Turkish- or Arabic-speaking guide and jotted them down in situ. ${ }^{44}$ How far Luke progressed in his Arabic studies is unknown. He evidently knew enough to be appointed as the fourth Thomas Adams professor on his return to Cambridge (this, however, is not to say very much: until well into the eighteenth century the chair was held as a sinecure by men who knew little or no Arabic). Although he appears to have published nothing (excepting a poem in Ottoman Turkish to mark the birth of Prince James in 1688), there

A. Hamilton, 'Denton, Henry (c. 1640-1681)', ODNB, 2004, online edn [<http://www.oxford $\mathrm{dnb} /$ view/article/7514>, accessed 9 Dec 2014].

42 TNA, SP $105 / 15^{2}$ fol. $122^{\mathrm{r}}$.

43 BL, MS Harley 7021 , fol. $372^{\text {v }}$. Luke mentions his attempt to 'culture some houres' with 'a certain Shaml'y a native Arabian Christian', whom he met while awaiting a pass age to Jerusalem at Antalya. It is not entirely clear, however, whether Luke conversed with Shaml'y in Arabic ('in which he [Shaml'y] is very well skilled in reading and writing') or in Turkish (which he 'did not read [...] at all currantly by reason of the diversity of pronuncia[ti]on').

44 Luke notes at one point in his journal (Bodl. Oxf., MS Tanner 93, fol. 145 $5^{\mathrm{v}}$ ) that he travelled to Jerusalem in the company of a Turk, taking 'Arabians as we passe for our guard, going among wolves thinking it necessary to engage wolves for our defence'. On his errors see, for example, BL, Ms Harley 7021, fol. $395^{\mathrm{r}}$ where he notes among 'the 5 villages which still

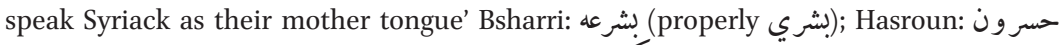

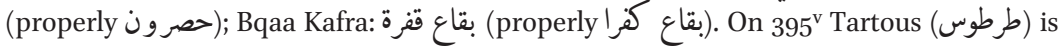
erroneously given as حصر نط: 
is some evidence that he taught Arabic and that he read at least parts of the Qur'an in the original language. ${ }^{45}$

\section{North Africa}

Outside Syria and Turkey, the most significant community of English merchants in the Arabic-speaking world resided in the independent sovereign state of Morocco. As early as the mid sixteenth century, the English operated a steady trade with the North African kingdom. ${ }^{46}$ In 1585 Queen Elizabeth granted letters patent for the establishment of the Barbary Company; although the Company failed to maintain a foothold in North Africa, the Crown continued to appoint an ambassador to Morocco throughout the seventeenth and eighteenth centuries.

As in Aleppo, there are isolated reports of English merchants and officials residing in Morocco who apparently learned Arabic. A letter of 1572 from a Moroccan customs officer mentions one Thomas Owen living and trading in Morocco who understood Arabic. ${ }^{47}$ Jezreel Jones, who served as British envoy to Morocco from 1704, was well known for his fluency in Arabic, and later served as translator to the Moroccan ambassador. ${ }^{48}$ The consulships on the North African coast at Tripoli, Tunis, Algiers, and Tangier (maintained not primarily for trade, but to protect English shipping against acts of piracy) appear to have provided fewer opportunities for learning Arabic. Thomas Baker, consul at Tripoli between 1677 and 1685 , conducted most of his official dealings with the Dey of Algiers in Turkish and Italian, but complained that there was

45 For Luke's poem, see Illustrissimi principis ducis Cornubiae et comitis Palatini, \&c, genethliacon, Cambridge, 1688, sig. B $3^{\mathrm{r}}$. Luke's contribution is headed 'Hendecasyllabi Turcici'; Geoffrey Roper has described it as 'a poem in rather strange Ottoman Turkish': G. Roper, 'Arabic Printing and Publishing in England before 1820', British Society for Middle Eastern Studies, 12.1, 1985, pp. 12-32. Martin Eagle referred to Luke in a letter to John Covel as

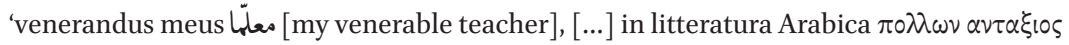
$\alpha \lambda \lambda \omega \nu$ ' [worth many others in Arabic letters]', BL, Add MS 22911, fol. 82 $2^{\mathrm{r}} / 163$ (my thanks to Anthony Ossa-Richardson for his help in deciphering this passage). For Luke's reading of the Qur'an, see BL, Ms Harley 7021, fol. $415^{\mathrm{r}}$.

46 T.S. Willan, Studies in Elizabethan Foreign Trade, Manchester, 1959, pp. 92-106.

47 N. Matar, Turks, Moors, and Englishmen in the Age of Discovery, New York, 1999, p. 64.

48 J. Black, British Diplomats and Diplomacy, 1688-180o, Exeter, 2001, p. 85; J.F.P. Hopkins, Letters from Barbary 1576-1774: Arabic Documents in the Public Record Office, Oxford, 1982, p. 36. Many of Jones's translations are bound in BL, Add Ms 61542, Blenheim Papers, vol. ccccxlii. 
'noe man in all this Country being able to boast a moderate accomplishment in both Languages'. 49

As in Syria and Turkey, where we do find examples of individuals studying Arabic abroad more systematically, these tend to be for reasons other than their commercial or diplomatic concerns. Lancelot Addison, who had been part of a circle of students with interests in Oriental topics at Queen's College, Oxford during the Interregnum, spent seven years as a chaplain to the military garrison at Tangier between 1663 and $1670 .{ }^{50}$ The list of 'Moorish words' appended to Addison's later West Barbary (1671) indicates at least some familiarity with the Arabic language; however, there is no evidence that Addison progressed very far in his studies. ${ }^{51}$ Similar examples can be found in the eighteenth century. In 1707, after graduating from Queen's College, George Holme served as a chaplain to the English factory in Algiers. In a letter to the Bishop of London, Henry Compton, he noted his plan to inform [him]self of the Customes of this Country, \& to learn the Turcick \& Arabian Languages.' ${ }^{52}$ A year later, Holme wrote to Compton about his receiving 'a yearly allowance for my encouragement \& support in the study of the Oriental Languages. ${ }^{53} \mathrm{In}$ the 1720 S Thomas Shaw, another Queen's student, spent nearly a decade in the same position, during which time he also learned some Arabic. Shaw's later Travels, or Observations relating to Several Parts of Barbary and the Levant (1738) demonstrates at least a basic acquaintance with the language; Shaw also took an interest in the Shawiya (or Chaouïa) dialect of the Berber language spoken by the Berbers of eastern Algeria. ${ }^{54}$

49 Piracy and Diplomacy in Seventeenth-Century North Africa: The Journal of Thomas Baker, English Consul in Triploli 1677-1685, ed. C.R. Pennell, Rutherford, NJ, 1989, p. 152.

50 A. Hamilton, 'Addison, Lancelot (1632-1703)', ODNB, online edn. [<http://www.oxforddnb. com/view/article/157>, accessed 8 Dec 2014]; W.J. Bulman, Anglican Enlightenment: Orientalism, Religion and Politics in England and its Empire, 1648-1715, Cambridge, 2015.

$51 \quad$ See 'An Index of Moorish Words', appended to L. Addison, West Barbary, or, A Short Narrative of the Revolutions of the Kingdoms of Fez and Morocco, Oxford, 1671. Some of the transcriptions in this list are highly tenuous: for example 'Abdel Crim Nacsis' for and 'Abdel Hader Alfiftoah' for عبد لله الكريم الحبـ الحبت

$5^{2}$ G. Holme to H. Compton, 1 Nov. 1707, Bodl. Oxf., Ms Rawl. C. 985, fol. 80

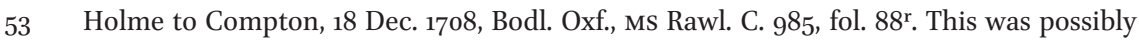
connected to the the Lord Almoner's fund; see L.S. Sutherland, 'The Origin and Early History of the Lord Almoner's Professorship of Arabic at Oxford', Bodleian Library Record, 10, 1930, pp. 166-77; Bodl. Oxf. ms Rawl. C. 933, fol. 164 ${ }^{\mathrm{r}}$.

T. Shaw, Travels, or Observations relating to Several Parts of Barbary and the Levant, Oxford, 1738 ; see the 'Vocabulary of the Showiah Tongue', appended p. $5^{2}$. 
The few cases cited above might lead us to reconsider some of the more emphatic statements concerning the total lack of interest of merchants in learning Arabic. It is certainly possible that further research into the voluminous papers of Englishmen (and the limited materials pertaining to English women) residing in North Africa and the Middle East before the nineteenth century would turn up more examples. It is possible too, of course, that many more individuals learned and conversed in Arabic but left no written traces of their activities. If so they have been lost to history. One thing can be said with certainty. The seventeenth century witnessed a great surge of institutional investment in Arabic studies in England. Very little of this, however, was geared towards training merchants and diplomats with the linguistic skills necessary to live and work in the Arabic-speaking world. The Laudian professor at Oxford, Thomas Hyde, whose own interests were very far from practical, was provided with financial support to train diplomatic translators, a task which he himself had undertaken in the 1690 s. ${ }^{55}$ Yet the project appears to have stalled. Nor did the Levant Company invest anything in encouraging its staff to learn Arabic. Although, as we have seen, the Levant Company offered some limited funds to promote the study of Italian, Arabic was evidently not deemed a necessity.

This absence of institutional investment is reflected by the lack of grammars or dictionaries produced during this period geared towards practical ends. Although Christian Ravius stressed the utility of Arabic for traders in the East, his 'general grammars' would have been of almost no practical use. Placing Arabic alongside the Hebrew, Samaritan, Chaldee (i.e. Aramaic), Syriac, and Ethiopic languages, they clearly reflected the historical-antiquarian and not the utilitarian interest in the language. The greatest Dutch Arabist of the early eighteenth century, Albert Schultens, reissued Erpenius's Arabic grammar with a long prefatory discourse setting out the role of Arabic in recovering biblical Hebrew. The same preoccupations characterized the grammar prepared by the Cambridge professor Leonard Chappelow. Chappelow amended the transliterations into Latin characters in Erpenius's work to reflect, he claimed, the pronunciation 'in use among the inhabitants of Arabia. ${ }^{66}$ Yet his edition was intended for missionaries and for scholars, not for merchants. The situation was somewhat different for Turkish. William Seaman, who had served in Istanbul under the ambassador Peter Wyche, produced a Turkish grammar in 1670 which - although written in Latin and conceived of primarily as serving Seaman's evangelical objectives - was sent to the English factories in

55 T. Hyde to J. Ellis, 26 Sept. 1698 , BL, Ms Add. 28927 , fol. $94^{\mathrm{v}}$.

56 L. Chappelow, Elementa linguae Arabicae ex Erpenii Rudimentis ut plurimum desumpta, London, 1730, p. ii. 
Izmir and Aleppo. ${ }^{57}$ Thomas Vaughan, who had been a merchant at Izmir, adapted Seaman's work in an English version specifically designed for the use of merchants residing abroad. ${ }^{58}$ However, it was not until well into the eighteenth century that a similar task was undertaken for Arabic. When this did occur, it was not initiated by the Levant Company, but by what by then had become its more economically and politically significant rival, the English East India Company.

\section{John Richardson and the East India Company}

The world of East Asia into which the East India Company's ships set sail in the sixteenth century was a more complex linguistic environment than the Ottoman Levant or North Africa. These complexities would pose many challenges to the diplomats and merchants who attempted to penetrate this world. As Sanjay Subrahmanyam has pointed out, when Thomas Roe addressed the emperor Jahāngīr at the Mughal court in 1616 he was forced to speak broken Spanish to an Italian interpreter, who then translated into Turkish; a Safavid prince then translated the Turkish into Persian. ${ }^{59}$ Negotiating with a number of different Islamic polities, Arabic could occasionally come in use. When James Lancaster addressed the nobles of the sultanate of Aceh on the northern tip of Sumatra, he conducted the business in Arabic using a Jew from the Barbary Coast 'who spake that language perfectly'. ${ }^{60}$ When established English factories came into being along the western and eastern coasts of India, a new vocabulary of words derived from Arabic peppered the correspondence which flowed back to London. ${ }^{61}$

However, it was the transformation of the East India Company from a trading corporation into a political and colonial administration in the second half of the eighteenth century that injected a new utilitarian strain into the study of Arabic. Arabic studies in the English universities are generally thought to have

57 W. Seaman, Grammatica linguae Turcicae, Oxford, 1670; TNA, SP 105/153, fol. $94^{\mathrm{v}}$. On Seaman see A. Hamilton, 'Seaman, William (1606/7-1680)', ODNB, 2004, online edn [<http:/// www.oxford.com/view/article/24986>, accessed 1o Dec 2014].

$5^{8}$ T. Vaughan, A Grammar of the Turkish Language, London, 1709.

59 S. Subrahmanyam, 'Frank Submissions: the Company and the Mughals between Sir Thomas Roe and Sir William Norris', in The Worlds of the East India Company, eds H.V. Bowen, M. Lincoln, and N. Rigby, Woodbridge, 2002, pp. 69-96 (83).

60 M. Ogborn, Indian Ink: Script and Print in the Making of the English East India Company, Chicago, 2007, p. 6 o.

61 G. MacLean and N. Matar, Britain and the Islamic World 1558-1713, Oxford, 2011, p. 89. 
declined during the eighteenth century. The foundation of the Laudian and Thomas Adams chairs, the brilliant career of Edward Pococke, and the massive expansion of the Oriental holdings of the Bodleian Library had made England, and Oxford in particular, into a leading centre of Oriental scholarship. Yet none of Pococke's students were able to replicate his achievements. Whereas a number of lesser-known figures continued to work within the parameters mapped out by Pococke's work - Thomas Hyde, Thomas Hunt, Jean Gagnier, and Johannes Uri at Oxford and Simon Ockley and Leonard Chappelow at Cambridge - Pococke's magnum opus, the Specimen historiae Arabum (1650) remained unsurpassed until the nineteenth century. ${ }^{62}$ In 1790 Joseph White, who as Laudian professor prepared a new edition of Pococke's work, wrote damningly to a colleague in the Netherlands that 'nothing can be lower than the state of Oriental literature in this country'.63

Yet alongside this narrative of decline, new trends began to emerge. Firstly, an increasing number of texts were published in the vernacular. Whereas Pococke's Arabic scholarship had been predominantly Latinate, reflecting a largely continental readership, Simon Ockley's The History of the Saracens (1708-18) and George Sale's English translation of the Qur'an (1734) catered to a growing market of English readers. Secondly, the expanding British empire in Asia opened up new horizons within Oriental studies. This had been evident in the work of Thomas Hyde, who requested East India Company merchants to procure manuscripts for him, and whose Historia religionis veterum Persarum (1700) pioneered the study of Persian antiquities. ${ }^{64}$ It was also apparent in the attempt in the late 1760 s of Warren Hastings, the future governor-general of Bengal, to institute an Oxford chair in Persian, the administrative language of the Mughal empire which the British colonial government would inherit. ${ }^{65}$ Yet it would come to fruition in the career of the most brilliant British Orientalist of the eighteenth century, William Jones. After pursuing his Arabic studies at Oxford, Jones soon turned his attention to Persian. His A Grammar of

62 This view of the decline of Arabic studies is set out in Toomer, Eastern Wisedome, pp. 30614.

63 J. White to H.A. Schultens, 3 Aug. 1790, LUL, Ms B.P.L. xiii.

64 P.J. Marshall, 'Oriental Studies', in The History of the University of Oxford, ed. T.H. Aston, 8 vols, Oxford, 1984-94, vol. 5: 'The Eighteenth Century', eds L.S. Sutherland and L.G. Mitchell, pp. 551-63, (557). See also A. Hamilton, 'The Learned Press: Oriental Languages', in The History of Oxford University Press, General Ed. S. Eliot, 3 vols, Oxford, 2013, vol. 1, 'Beginnings to 1780', ed. I. Gadd, pp. 399-417, (409-11, 414-15).

65 P.J. Marshall, 'Warren Hastings as Scholar and Patron', Statesmen, Scholars and Merchants: Essays in Eighteenth-Century History presented to Dame Lucy Sutherland, eds A. Whiteman, J.S. Bromley, and P.G.M. Dickson, Oxford, 1973, pp. 242-62 (245-6). 
the Persian Language (1771) struck a new tone in the study of eastern languages. Critical of the legacy of Renaissance erudition, Jones attempted to fuse Oriental scholarship with a heightened sensitivity to beauty, elegance, and taste. Yet he also placed a new emphasis on utility. Jones's audience were no longer the bookish divines ensconced in college libraries, but the cultured professionals required by the expanding bureaucracy of British India. His intention was not to aid the scholar navigating the grammatical intricacies of a polyglot Bible, but to assist the colonial administrator to read and write diplomatic letters, and to converse with both fluency and elegance.

If for earlier generations Arabic had been of interest primarily due to its close relationship with Hebrew, then for Jones it was Arabic's proximity to Persian which made its acquisition a necessity. The administrators in Bengal, wrote Jones, would 'regret their ignorance of the Arabick language', without which their knowledge of Persian 'must be very circumscribed and imperfect.' ${ }^{66}$ The same reasoning inspired the first Arabic grammar printed in English: John Richardson's A Grammar of the Arabic Language of 1776 . In a dedication to the chairman, deputy, and directors of the East India Company, Richardson stressed the 'general usefulness' of Arabic, in particular for the 'just understanding of that Eastern language of correspondence and state affairs, the Persian'. His English primer would, he hoped, smooth the way to a language 'hitherto conceived so difficult, that few of your servants have had courage to begin it'. Like Jones, Richardson scorned the pedantry of the scholar - 'the perplexing obscurity and unengaging manner of grammarians'. His concern was with gentlemen: men of business, for whom the exigencies of commerce, war, and political government were more pressing than any 'abstract theoretical disquisitions, delivered in an obscure Latin idiom'. His Grammar, therefore, was a practical one, which stuck to essentials, eschewed irrelevant niceties, and attempted to illustrate rules through examples. ${ }^{67}$

Richardson's preface, however, over-emphasized the novelty of his work. The book was very closely modelled on Erpenius's grammar of a century and a half earlier. Frequently, Richardson simply translated Erpenius's Latin text; ${ }^{68}$ the 'paradigms', or tables of verbs, were reproduced directly from Erpenius. Richardson's innovations were, firstly, to reorder the material. Most substantially, he placed Book II, on nouns, before the section on verbs, there being

66 W. Jones, A Grammar of the Persian Language, 2nd edn, London, 1775, p. x.

67 J. Richardson, A Grammar of the Arabic Language, London, 1811, pp. iv, iii, vii, xi.

68 C.G. Killean ('The Development of Western Grammars of Arabic', Journal of Near Eastern Studies, 43.3, 1984, pp. 223-30) perhaps goes too far, however, in stating simply that Richardson translated Erpenius into English. 
'no impropriety', in Richardson's judgment, 'in following the mode generally practised in teaching the European languages' ${ }^{69} \mathrm{He}$ also moved Erpenius's discussion of the mutations of the long vowels from Book I, on the alphabet, to Book III, on verbs. Many of Erpenius's observations deemed non-essential were relegated to the footnotes. Secondly, Richardson added much new material. Some of this reflected his concern with practical utility. In an expanded section on pronunciation, for example, he drew attention to the broad variety of inflections inevitable in a widely-diffused, living language. The difficult Arabic consonant $\dot{\varepsilon}$ 'ghayn', Richardson noted, although standardly pronounced 'as $g h$ in ghastly', in India assumed an aspirated ' $r$ ' sound, 'resembling in some measure the Northumberland $r^{\prime} .{ }^{70}$ Richardson also added numerous extracts of Arabic texts intended to illustrate grammatical rules by example. Some of these were drawn from the printed Arabic works produced in Europe during the preceding two centuries. To illustrate the thirteen conjugations of the triliteral verb, for example, he gave a section from the Mukhtașar ta'rïkh al-duwal by Bar Hebraeus, Grigōriyōs Abū l-Faraj (printed in Pococke's edition in $165^{\circ}$ and 1663). Yet the majority reflected the new taste for Arabic poetry and literature; as a supplement to the grammar, Richardson printed an extract from the Arabian Nights from a manuscript belonging to William Jones. ${ }^{71}$

Whether Richardson's grammar achieved its aim of encouraging the East India merchants to study Arabic is less clear. Certainly among the young men working under Hastings in Bengal, several turned their hands to learning languages. David Anderson, for example, attempted to acquire Arabic in the early 1770 s as a means to achieving 'a perfect knowledge of Persian. ${ }^{72}$ Moreover, there is some evidence that the allure of employment in India inspired students to study Arabic in the British universities. In 1786 James Robertson, professor of Hebrew at the University of Glasgow, wrote to the Netherlands concerning Whitelaw Ainslie, a student of his who had 'attended my Lecture on the Arabick and Persian languages with a view of being employed by our East India Company', and had 'made great progress in the study of these languages'; Ainslie later served as a surgeon to the British garrison at Chingleput. ${ }^{73}$

69 Richardson, A Grammar, p. 19.

$70 \quad$ Ibid., p. 9 .

71 James Robertson (J. Robertson to H.A. Schultens, 31 Mar. 1778, LUL, MS B.P.L. xiii) thought that Richardson's neglecting to add vowel points to these extracts suggested that he 'has had no great experience at least in teaching the Arabick language'.

72 Quoted in Marshall, 'Warren Hastings as Scholar and Patron', p. 259.

73 J. Robertson to H.A. Schultens, 22 Sept. 1786, LuL, MS B.P.L. xiii; B.D. Jackson, 'Ainslie, Sir Whitelaw (1767-1837)', rev. J. Mills, ODNB, 2004 [<http://o-www.oxforddnb.com.catalogue.ulrls.lon.ac.uk/view/article/239>, accessed 18 Dec 2014]. 
It is likely, however, that 'such men were a small minority among Englishmen (and, we should add, Scotsmen) in India'. ${ }^{74}$

Nevertheless, Richardson's grammar was succeeded by a more ambitious publication: a new dictionary of Arabic and Persian. This project had its origins in the early 1770 in a plan to produce a new Oriental dictionary. The model for the work was the Thesaurus linguarum orientalium (1680-87), a dictionary of Turkish, Arabic, and Persian prepared by Franz Mesgnien Meninski who had served as interpreter of Oriental languages to the Habsburg monarchy in Vienna. A group of Oxford scholars, including John Swinton, Thomas Hunt, Johannes Uri, Joseph White, and no doubt Richardson himself, intended to augment the vocabulary in Meninski using the lexicons of Jacobus Golius, Antonio Giggei, and Edmund Castell for the Arabic, and the numerous manuscripts in the Bodleian and other private collections for the Persian. From the outset, the support of the East India Company was deemed essential to the success of the project, and the Company was solicited to subscribe in advance for a number of copies as a security for the vast expense of the undertaking, which included the cutting of an entirely new set of Persian types. ${ }^{75}$ By October 1770 , the Company had given its support. However, the plan was now no longer to produce an entirely new dictionary, but to reissue Meninski's work. ${ }^{76}$ At this stage, William Jones was at the head of the project, and had used his growing reputation as a scholar of Persian to garner institutional support, both in England and on the Continent. ${ }^{77}$ Richardson was also closely involved with the work. By the following year, the dictionary was said to be 'preparing for the press', and was scheduled for printing in April. ${ }^{78}$

In the event, the book never appeared (at least not in England: a new edition of Meninski was issued at Vienna in 1780 under the patronage of the empress Maria Theresa). ${ }^{79}$ By the mid 1770 J Jones had immersed himself in his legal practice; Thomas Hunt died in 1774, and John Swinton three years

74 Marshall, 'Warren Hastings as Scholar and Patron', p. 259.

75 BL, IOR, Mss Eur G37/17/66.

76 G. Sharpe to J. Richardson, 25 Sept. [1770], BL, IOR/E/1/54, fol. 209; W. Crichton to EIC, 3 Oct. 1770, BL IOR/E/1/54, fols 210-11; S. Hallifax to EIC, 3 Oct. 1770, BL, IOR/E/1/54, fol. 220.

W. Jones to EIC, 30 Dec. 1770, BL, IOR/E/1/54, fol. 466. See also the French-language prospectus printed at London in June 1771 (BL, 111.g.65); here Jones noted that the project had also received the support of the Levant Company, and that the editors intended to include translations of the Oriental words into Latin, English, Italian, Portugese, and French.

78 BL, IOR $/ \mathrm{E} / 1 / 54$, fols $28^{\mathrm{r}}-29^{\mathrm{v}}$.

79 F. à Mesgnien Meninski, Lexicon Arabico-Persico-Turcicum, 4 vols, Vienna, 1780. 
later. By the beginning of 1776 , Richardson alone was at work on the book in the form in which it would eventually appear: an English dictionary of Arabic and Persian, under the patronage of the University of Oxford and the East India Company..$^{80}$ The first volume was printed the following year. Following Meninski, Richardson listed the interspersed Arabic and Persian vocabulary alphabetically, distinguished only by an 'A' or 'P' preceding each individual entry. Contrary to almost all dictionaries in the Arabic lexicographical tradition (and to Jacobus Golius's 1653 Lexicon), this meant that the words were not grouped under their roots. Richardson's dictionary also had the disadvantage of not listing the plurals of many Arabic nouns. The Arabic vocabulary was largely derived from Meninski (who in turn had relied heavily on Golius); yet Richardson omitted a substantial number of Arabic words reflecting his principal concern with Persian. ${ }^{81}$ Volume two, which appeared three years later, was more innovative. For the first time, Richardson attempted to produce an English to Arabic and Persian vocabulary. This clearly reflected the utilitarian emphasis of his work: his dictionary was for men who required an active grasp of the Persian (and thus of the Arabic) language. In it, can also be discerned the conjunction of scholarship and colonialism which, through the work of Edward Said, has come to define the contemporary resonance of the term 'Orientalism'.82 Identifying Persian and Arabic synonyms for English words was, for Richardson, part of a broader attempt to 'naturalize, in the East, our European ideas, by clothing them in an Eastern dress'. 83

Whatever its shortcomings (a later editor found 'numerous errors in translation'), Richardson's dictionary had a long afterlife. It was reprinted in 1800 and was re-issued in abridged form in $1810{ }^{84}$ It then went through two further

80 J. Richardson to H.A. Schultens, 6 Jan. 1776, LUL, MS B.P.L. xiii (requesting 'a list of Arabick words not in Golius') which he had heard about through James Robertson at Edinburgh.

81 This was the opinion of Francis Johnson, editor of a third edition of the dictionary, who after 'a rigid comparison' of the two works judged Richardson's dictionary to be 'little else than a limited translation from the great Thesaurus of Meninski' and found that Richardson had omitted 'many thousands of Arabic words': J. Richardson, A Dictionary, Persian, Arabic, and English, ed. F. Johnson, 3rd edn, London, 1829, p. 7 .

82 E. Said, Orientalism, New York, 1978. For further reflections on the relationship between scholarship and colonialism in the context of British India, see Marshall, 'Warren Hastings as Scholar and Patron' and Ogborn, Indian Ink, pp. 198-265.

83 J. Richardson, A Dictionary, Persian, Arabic, and English, 2 vols, London, 1777-80, vol. 1, p. iii.

84 J. Richardson, A Dictionary, Persian, Arabic, and English, 2 vols, London, 180o; C. Wilkins, A Vocabulary, Persian, Arabic, and English; abridged from the Quarto Edition of Richardson's Dictionary, London, 1810. 
nineteenth-century editions prepared by the Orientalists Charles Wilkins (1806-10) and Francis Johnson (1829); ${ }^{85}$ Johnson's revised edition provided the basis for his own $185^{2}$ A Dictionary, Arabic, Persian, and English; this work, in turn, was re-issued by F.J. Steingass in 1892, and continued in print well into the twentieth century. ${ }^{86}$ In its various re-incarnations, the dictionary also achieved Richardson's aim of providing a practical aid for the East India Company's administrators. The Company purchased 150 copies of the first edition, and many more were sent out to Bengal and Madras; in the nineteenth century, later editions were distributed for use at the Fort William and Madras Colleges.

\section{Conclusion: The Endurance of Scholarship}

Richardson's dictionary succeeded in uniting two motivating factors behind the study of Arabic in early modern Europe: the interests of the scholar and the practical requirements of the merchant or the diplomat. The work was produced through a combination of the financial support of the East India Company with the intellectual resources of the University of Oxford. Its long publication history coincided with the development of a number of new educational institutions where Arabic and other languages of the Indian subcontinent were taught for practical ends, notably Fort William College (established 180o) and the East India College at Hertford (afterwards Haileybury; established 1806).

However, the English had come late to the game. As early as 1551, the Venetians had founded a language school in Istanbul to train Italian youths for the diplomatic service. ${ }^{87}$ The French, under the guidance of Louis XIV's minister Jean-Baptiste Colbert, established a school for the teaching of Arabic, Turkish,

85 J. Richardson, A Dictionary, Persian, Arabic, and English, ed. C. Wilkins, 2 vols, London, 1806-10; Richardson, Dictionary, ed. F. Johnson. These two works replaced the original folio with quarto editions. The 1829 edition has been reprinted several times (most recently in 1998) by Sang-e-Meel, Lahore.

86 F. Johnson, A Dictionary, Persian, Arabic, and English, London, 1892; F.J. Steingass, A Comprehensive Persian-English Dictionary: including the Arabic Words and Phrases to be met with in Persian Literature, London, 1892; the latter work went through a number of twentieth-century editions up until 1977 .

87 E. Dursteler, Venetians in Constantinople: Nation, Identity, and Coexistence in the Early Modern Mediterranean, Baltimore, 2006, p. 37; I. Palumbo Fossati Casa, 'L'École vénitienne des “Giovani di Lingua”, in Istanbul et les langues orientales, ed. F. Hitzel, Paris, 1997, pp. 109-22. 
and Persian in $1669 .{ }^{88}$ The Orientalische Akademie in Vienna was founded with similar aims in 1754, and in 1766 a school for Oriental languages was established in Istanbul under the Polish king Stanisław August Poniatowski. ${ }^{89}$ Moreover, when English commercial and colonial interests did stimulate new scholarly work on Arabic grammar and lexicography, Arabic was only ever a secondary interest: as we have seen, in Richardson's work Arabic was valued chiefly because its grammar and so much of its vocabulary were thought to have influenced Persian. The truly pioneering work of the British Orientalists in India was not in Arabic, but in the east Asian languages which then were terra incognita for European scholars: Bengali, Urdu, and, most significantly of all, Sanskrit.

Finally, Richardson's work brings to the fore the remarkable longevity of the earlier writings of humanist scholars who had done so much to advance the study of Arabic in the sixteenth and seventeenth centuries. Although the institutional context of Richardson's work - his success in garnering financial support from a corporation - was new, the content of his scholarship was almost wholly derivative. His grammar was a reworking of a book produced more than a hundred and fifty years earlier by Thomas Erpenius. The Arabic vocabulary of his dictionary was derived (via Meninski) from the mid seventeenth-century work of Erpenius's successor at Leiden, Jacobus Golius. In this sense, the claims of Raphelengius, Erpenius, and others that their work would have some utilitarian value turned out to be correct. Patrons of scholarship, then as now, would do well to heed the fact that it took more than a century for these practical applications to be realized.

88 A. Pippidi, 'Drogmans et enfants de langue: la France de Constantinople au XVII ${ }^{\mathrm{e}}$ siècle', in Istanbul et les langues orientales, pp. 131-40.

89 V. Weiss von Starkenfels, Die kaiserlich-königliche orientalische Akademie zu Wien, Vienna, 1839, p. 7; Tadeusz Majda, 'L’École polonaise des langues orientales d'Istanbul au XVIII ${ }^{\mathrm{e}}$ siècle', in Istanbul et les langues orientales, pp. 123-28. 